\title{
NATO Response Force: Rapid? Responsive? A Force?
}

\section{Michael Mihalka*}

The NATO Response Force (NRF) was intended to make NATO responsive to the security needs of the twenty-first century. However, by U.S. standards it is unlikely to be rapid, responsive, or much of a force. Nevertheless, the NRF will prove the most important vehicle for adapting European forces to the needs of modern expeditionary ventures.

The United States proposed a "NATO Response Force" at a meeting of NATO defense ministers in September 2002. U.S. Secretary of Defense Donald Rumsfeld cautioned his colleagues, "If NATO does not have a force that is quick and agile, that can deploy in days or weeks rather than months or years, then it will not have capabilities to offer the world in the twenty-first century." The Americans had become increasingly concerned that the Europeans had become preoccupied with the needs of the 1990 - that is, to provide stabilization forces after a conflict - and were ignoring the new threats that had appeared after the terrorist attacks of September 2001. "There are no more threats to NATO from within Europe, but from a nexus of terrorism and weapons of mass destruction," a U.S. official demurred. "NATO needs an expeditionary force, a strike force, that can move fast."

The NATO Secretary-General, Lord George Robertson, took a similar tack and urged the allies "to think carefully about the role of this alliance in the future, not least in protecting our citizens from criminal terrorists and criminal states." He stressed that the NRF would not compete with the EU's Rapid Reaction Force. "The bottom line is that NATO's Response Force and the EU's Rapid Reaction Force will be ... complementary," he insisted. ${ }^{2}$

\section{Background}

The rationale for the NRF was laid out in an article by Hans Binnendijk and Richard Kugler. ${ }^{3}$ They argued that the Defense Capabilities Initiative (DCI) adopted by NATO at the Madrid Summit in 1997 had largely proved a failure because it lacked focus and a sense of priorities. The five major categories of the DCI were sound-deployability and mobility; sustainability and logistics; effective engagement; survivability of forces and infrastructure; command, control, and information systems - but they concentrated on inputs rather than outputs. Binnendijk and Kugler were more concerned about

* Dr. Mihalka teaches at the US Army Command and General Staff Officers College at Fort Leavenworth, Kansas.

1 Steven Erlanger, "Rumsfeld Urges NATO to Set Up Strike Force," New York Times, 25 September 2002.

2 “'NATO Response Force is no Rival to EU Plan,' says Robertson," Deutsche Presse-Agentur, 8 October 2002.

3 Hans Binnendijk and Richard Kugler, “Transforming European Forces," Survival 44:3 (Autumn 2002): 117-32. 
whether European forces could fight effectively alongside U.S. forces rather than about whether some European forces had capabilities comparable to those of U.S. forces. They observed that, following the DCI approach, "At best, in times of crisis, NATO will still be cobbling together an untrained multinational force rather than drawing upon an integrated and flexible force that already exists." This is a critical observation: American forces are deemed to be more effective not only because they have forces equipped with the some of the latest technologies, but because they train and exercise together in a joint fashion to perform expeditionary missions. In other words, it is not the capabilities that make the force, but the demands placed on the force that makes the capabilities.

\section{The Europeans Drag Their Feet}

For their part, the German and French reaction to the concept of the NRF was guarded and tentative. Joschka Fischer, the German minister of foreign affairs, told his parliament, "We view the American proposal for a multi-national response force as constructive." Although he said the force was needed to deal with the "nightmare of a major terrorist attack," Fischer said that Germany could only provide troops for such a force under three conditions: ${ }^{4}$

- The NATO Council would have to maintain the right to decide on deploying the rapid reaction force;

- Germany's Parliament would first have to approve any deployment before troops went into combat;

- Any NATO force would have to be compatible with the planned 60,000-member European Union (EU) Rapid Reaction Force due to be set up the following year.

These terms were underscored by Defense Minister Peter Struck, who said, in an apparent reference to the United States: "There must be consensus in NATO-one country cannot decide alone."

Struck wasn't even sure that the NRF would be used for offensive operations. When asked whether the NRF could be used for offensive operations, Struck responded,

These are matters that must be discussed in detail. So far, there exists only the general idea of installing such a NATO force, while so far many states reserve intervention forces for themselves. But to the new force, also, applies NATO's principle of consensus. It would be wrong to assume that the United States could simply use the Response Force in any corner of the world. Everything is done through a resolution by all nineteen, or soon to be twenty-six, member states. ${ }^{5}$

4 "Germany Sets Terms for Backing NATO Rapid Reaction Force," Deutsche Presse-Agentur, 14 November 2002.

5 Gerold Buechner, "'Not Every Country Must Be Able to Do Everything'-Defense Minister Struck on NATO Response Force, the Defense Budget, and Iraq," Berliner Zeitung, 21 November 2002. 
For her part, the French Defense Minister Michelle Alliot-Marie said that, although she supported the concept, the force should not operate outside Europe, be used in a pre-emptive manner, or operate without a UN mandate. The political requirements of first securing a UN mandate and then parliamentary approval from the states involved would seem to take the "rapid" out of any rapid reaction force.

\section{The U.S. Marine Expeditionary Brigade as a Model for the NRF}

The NRF is a joint and combined force of about 20,000 troops composed of national contributions. The ground element will be brigade-sized with special force units, a joint naval force, and when fully functional will be capable of 200 combat sorties a day. It should be ready to deploy within five days, and have sufficient organic logistics to operate for thirty days. The force will have a period of unit training, then six months of interoperability training, followed by six months on standby or deployment. The first two rotations, starting in October 2003, were kept small so as to provide a test bed for a force that was not intended to achieve full operational status before October 2006. A force generation conference will determine which forces countries will make available.

Conceptually, the force in the U.S. military that the NATO Response Force most closely resembles is the Marine Expeditionary Brigade, especially some aspects of the Fourth Marine Expeditionary Brigade (MEB) that was set up by the then-Commandant of the U.S. Marine Corps, General James L. Jones, as an anti-terrorism force in September 2001. ${ }^{6}$ It is no accident that General Jones was chosen to be the Supreme Allied Commander-Europe (SACEUR) after 9/11. The U.S. Marines brought a joint combined and expeditionary mentality to NATO in an era when it was sorely needed. The Fourth MEB (AT) consists of a Chemical, Biological Incident Response Force (CBIRF) and an Anti-Terrorism Battalion (AT Bn). It also includes the Marine Security Guard Battalion (MSG Bn) and Marine Corps Security Force Battalion (MCSF $\mathrm{Bn})$. The CBRIF element provides rapid response to chemical or biological threats. The Marine Corps Security Force Battalion also maintains two Fleet Anti-terrorism Security Teams (FAST).

The Second Marine Expeditionary Brigade (MEB), also known as Task Force Tarawa, perhaps provides the standard against which a NATO Response Force might be measured. An MEB and the NRF are roughly the same size and have roughly the same missions. The Second MEB is a scalable, combined force capable of conducting forced-entry missions and sustaining combat operations for up to sixty days. ${ }^{7}$ It has both fixed-wing and rotary organic air assets that are capable of operating out of expeditionary airfields established with organic assets. Mission requirements will determine the size-anywhere from four to seventeen thousand troops - of the Marine Air

6 See http://www.lejeune.usmc.mil/4thmeb/organization.htm, accessed 20 February 2004. See also, Al Hemingway, "At the Tip of the Anti-terrorism Spear: Though little known, the U.S. Marines maintain special anti-terrorism units," VFW Magazine (August 2002).

7 Cf., http://www.globalsecurity.org/military/agency/usmc/2meb.htm, accessed 14 April 2004. 
Ground Task Force (MAGTF) formed from the Second MEB. Using a variety of means, including amphibious shipping, strategic air, and pre-positioned equipment, the Second MEB can be deployed for action within five to fourteen days. The unit most recently saw service in Iraq.

\section{How Much and What Kind of Force Is Needed?}

Some authors have argued that the NATO Response Force of 20,000 troops is not large enough to be effective. ${ }^{8}$ Another author has argued that the NRF is nothing but "a token use of Europe's best military forces in the service of the U.S." These arguments are wrong in two very important senses. First, a quick examination of actual "short-notice" expeditionary operations since 1990 reveals very few operations where more than a brigade-sized force (around 5,000 ground troops) was used. Second, the number of actual forces dedicated to the NATO Response Force would probably be three-times the 20,000 figure, as these forces would need to train prior to coming on standby status, and would need to refit afterwards.

Only two "short-notice" operations have required more than a brigade-sized force since 1990. The first Gulf War involved around 700,000 U.S. and allied forces (against roughly 550,000 Iraqis), while the Iraq War of 2003 involved roughly 200,000. No European state would agree to use the NRF to fight alone against the forces of a major nation-state like Iraq. A more plausible scenario would be one where the United States is tied down in a major conflict (such as Iraq) when a transnational terrorist group conducts a mass casualty attack on the soil of a NATO member, and the NRF would be tasked to take out the training camps of the transnational terrorist group - in other words, a scenario very much like the one that occurred after 9/11 in Afghanistan.

Afghanistan, like almost all conflicts, has a number of unique aspects that make it difficult to generalize about future conflicts based on its example. As Anthony Cordesman has written, "Political and military uncertainties whose impact U.S. and British planners could not predict when the fighting began nearly all worked out in favor of the United States, Britain, and the Afghan opposition." Nevertheless, an examination of the sequence of events and deployments in Afghanistan might prove instructive.

The deployment to Afghanistan was not particularly speedy. The first air strikes did not occur until 7 October 2001. The U.S. took some care to ensure the political legitimacy of its actions, even though it did not intend to use NATO or the UN as the basis for command. Although several special forces units were deployed throughout the conflict, the first major units, (Marines) arrived in Kandahar on 25 November, two and a half months after the September 11 attacks. Very few of the battles during the Afghani-

8 For instance, Michael Clarke and Paul Cornish have argued that "a 'European strike force could be effective if it involved perhaps 40,000 troops...." Michael Clarke and Paul Cornish, "The European Defence Project and the Prague Summit," International Affairs 78:4 (2002): 777-88.

9 Anthony H. Cordesman, The Lessons of Afghanistan (Washington, D.C.: Center for Strategic and International Studies, 2002), 20-21. 
stan conflict involved more that 2,000 allied forces. About 2,000 allied forces participated in Operation Anaconda in March 2002, including 1,200 U.S. soldiers. The U.S. never committed more than 7,500 ground troops to the Afghanistan conflict. Despite the large size of the Afghani theater, the U.S. never deployed any formation larger than a few thousand troops.

The U.K. campaign against the Falkland Islands provides another example of expeditionary warfare. The British assault force numbered just 7,000 troops; around 4,000 troops landed on 21 May 1981. The Argentines had invaded the islands on 2 April. The delay in responding owed more to the distances involved (7,500 nautical miles) and the need to support the operation from the sea than to any lack of readiness of the forces. Several of the units involved - the 3 Para and the 40 and 42 Commando-were embarked on 7 April. Although the British received critical U.S. support, only British forces fought. Moreover, the U.K. could not assume that it could quickly gain air superiority, much less the kind of air supremacy that the U.S. has enjoyed in all of its recent conflicts.

Air power may pose a much more serious shortfall for the NRF and the Europeans, but the value of air power is often difficult to assess. Statistics from Operation Desert Storm (Gulf War I) and the operations in Serbia/Kosovo and Afghanistan show that the U.S. share of the sorties flown were 85,62 , and 92 percent respectively. ${ }^{10}$ The proportion of sorties flown by U.S. forces that involved precision-guided weapons were even higher: 89, 80 and 99 percent respectively. However, using sortie rates can be quite deceptive, as the total tonnage of munitions dropped by the U.S. relative to its allies is masked by these figures. In Afghanistan, B-52s and B-1s delivered 11,500 of the 17,500 weapons dropped -65 percent of the total —although they flew only 10 percent of the sorties. ${ }^{11}$ B-52s and B-1s also played prominent roles in the recent Iraq conflict. In fact, the European air forces have nothing comparable to a medium bomber in their inventory.

The missions suggested for the NRF also would not seem to require a ground element larger than a brigade. The FAQ prepared by SHAPE says the force's potential missions are as follows:

- It could be deployed as a stand-alone force for crisis response in efforts such as:

- Non-combatant evacuation operations (NEO);

- Support consequence management (CBRN events or humanitarian crisis situation);

- Crisis response operations, including peacekeeping;

- Support counter-terrorism (CT) operations;

- Embargo operations;

10 Cordesman, Lessons, 11.

11 Cordesman, Lessons, 5. 
- Deployed as an initial entry force to facilitate the arrival of follow-on forces in a JOA from a benign up to a hostile environment, with or without host nation support (e.g., peace enforcement);

- Deployed as a demonstrative force package in order to show the resolve of member nations (quick response operations to support diplomacy as required).

For operations against terrorists, the NRF would need to rely on special operation forces, so the composition of the NRF matters as much as its size. And, in fact, the SHAPE FAQ reads very much like the requirements for the U.S. Marine Expeditionary Brigade.

\section{How Fast?}

The NATO NRF requirement is that the force should be ready to deploy within five days, and that it should be able to sustain itself for thirty days. The SHAPE discussion of the NRF adds an important caveat: "when NATO decides to employ it." So there are several real problems in the speed with which the NRF could be deployed - the time it would take for NATO to use the force, the time it would take to get ready to deploy, and the time it would take to get the force into the field. This whole process would take a minimum of two weeks, and quite possibly longer.

Let's start with the deployment of the force. According to a recent RAND study assessing the requirement to deploy a Stryker brigade globally within 96 hours, "The main conclusion of this report is that a force with more than 1,000 vehicles cannot be deployed by air from CONUS to the far reaches of the globe in four days. However, with some mobility enhancements, it is possible to achieve deployment timelines on the order of one to two weeks, which is quite rapid for a motorized force." 12 In other words, even the U.S. military would have trouble deploying a brigade quickly; this does not say much for the potential speed of the NRF, which may lack important organic strategic lift capability, at least in the short term.

Alternatively, the NRF could be deployed by sea. After all, at seventeen knots, a sea force can move 2,000 nautical miles in five days. NATO recognizes the need for better strategic sealift capability, and recently concluded arrangements to secure several roll-on/roll-off ships.

However, there exist some very real issues concerning whether NATO will be able to quickly decide to send the force in the first place. The SHAPE FAQ on political decision-making and control of the forces once they are deployed contains few answers, and many questions. Many NATO members will almost surely insist that a UN mandate be secured before their troops can be deployed abroad. As can be seen from the following table, the publics in most European countries would greatly prefer that their

12 Alan Vick, David Orletsky, Bruce Pirnie, and Seth Jones, "The Stryker Brigade Combat Team: Rethinking Strategic Responsiveness and Assessing Deployment Options," Report No. MR-1606-AF (Santa Monica, CA: The RAND Corporation, 2002), xiv. 
government seek UN authorization, even if a country's vital national interests are at stake. Only in the U.K. is there a majority in favor of action without UN authorization.

Table 1. Percentage of respondents to the question: When vital interests of our country are involved, it is justified to bypass the UN (If needed: "vital interest means when stakes are high"). ${ }^{13}$

\begin{tabular}{lccccc}
\hline & $\begin{array}{c}\text { Agree } \\
\text { Strongly }\end{array}$ & $\begin{array}{c}\text { Agree } \\
\text { Somewhat }\end{array}$ & $\begin{array}{c}\text { Disagree } \\
\text { Somewhat }\end{array}$ & $\begin{array}{c}\text { Disagree } \\
\text { Strongly/ } \\
\text { Refuse }\end{array}$ & $\begin{array}{c}\text { Don't } \\
\text { Know }\end{array}$ \\
\hline U.K. & 25 & 27 & 22 & 20 & 6 \\
France & 15 & 22 & 39 & 30 & 3 \\
Germany & 14 & 24 & 32 & 27 & 3 \\
Netherlands & 14 & 25 & 34 & 22 & 5 \\
Italy & 13 & 25 & 26 & 28 & 8 \\
Poland & 12 & 25 & 27 & 17 & 19 \\
Portugal & 14 & 16 & 23 & 37 & 10 \\
U.S. & 36 & 21 & 18 & 20 & 5 \\
\hline
\end{tabular}

Many in the political leadership in Europe reflected the sentiments of their public over the need for a UN mandate in Iraq. The French President Jacques Chirac said, "Whatever the circumstances, France will vote no." He added, "War is always the worst solution." In March 2003, an opinion poll of French citizens showed that 64 percent opposed the war in Iraq without an authorizing UN resolution-and that 69 percent thought that France should veto any such resolution. The protracted debate over the second UN resolution over Iraq illustrates the difficulty of securing a consensus for action when there are serious policy differences involved. Even in the case of the September 11 attacks, the initial French elite reaction was at best lukewarm in favor of action, and only became so after French public opinion polls supported a decisive response.

Elite and popular sentiment ran strongly against the Iraq war even with UN authorization. The Spanish daily El Mundo claimed that "President Bush must not now reject the authority of the United Nations because "it does not bow to the interests of the USA." "14 The French Defense Minister Michelle Alliot-Marie said on 14 March 2003,

13 “Transatlantic Trends 2003," July 2003; available at: http://www.transatlantictrends.org/ apps/gmf/ttweb.nsf/0/DA5A3225751A264585256D78000D5F66/\$file/Transatlantic+Trends +Survey+Results+2003.pdf, accessed 19 February 2004.

14 FBIS Document ID: EUP20030314000310, 14 March 2003. 
at a meeting of EU defense ministers in Athens, "There is no possibility that France will participate in a military intervention without a UN resolution." ${ }^{\prime 5}$ Issues of global status seemed to matter as much as the credibility of the UN, or whether Iraq possessed weapons of mass destruction. One German commentator noted:

What weighs heavier, though, is the subjugation of the United Nations to U.S. military strategy: either you go with us or we do it with a coalition of the willing. This was an unpardonable challenge of Russia, the great power that was, and France, the would-be great power of today. ... This, not Iraq, is the real reason for the heap of rubble that threatens to bury the United Nations, NATO, and German-American relations. We are currently witnessing an unprecedented struggle for power with the aim to put Gulliver, in the past kept at bay by the Soviet Union, in chains again. The historic date was 5 March, when France, Germany, and Russia joined together to oppose the "hyperpower": a war resolution "would not be permitted." This was the renversement des alliances, the reversal of alliances - as in 1757, when "archenemies" France and Austria suddenly ganged up against Prussia under King Frederick. ${ }^{16}$

An examination of international opinion polls in the run-up to the intervention in Iraq reveals considerable popular opposition to the war, even with a UN resolution. For example, a January 2003 FORSA survey found 69 percent of Germans opposing the war. A poll conducted by the magazine Der Spiegel found 74 percent against the war. 57 percent of Danes opposed the war even with a UN mandate, and 79 percent in its absence. A Gallup International Poll released in early 2003 revealed that public opposition to the war was not greatly diminished by the presence of a UN mandate (see Table 2 below). The failure to find weapons of mass destruction in Iraq would make countries even more unwilling to commit forces without a clear and compelling casus belli and a UN mandate.

Although this opinion poll applied primarily to Iraq, it illustrates the problems of securing approval for action when the goals of the operation are not altogether clear.

Even with a UN mandate, the process of securing parliamentary approval in certain countries could be slow. To illustrate the difficulties posed by the requirements to go through UN and parliamentary approval, NATO staged an exercise in October 2003 specifically designed to focus on the utilization of the NATO Response Force. The Germans were skeptical, and the French dismissive. The French defense minister came to the exercise late, and left early. However, the German Defense Minister Struck was sufficiently impressed that he returned home and requested a change in parliamentary procedures that would allow a select committee of the Bundestag to approve an NRFtype deployment. The Social Democrat-Green majority in the German Parliament would have none of it. The SPD parliamentary group's spokesman on internal policy, Dieter Wiefelspütz, told the Berliner Zeitung that every future military operation

15 FBIS Document ID: GMP20030314000083; Athens Elevtherotipia, 14 March 2003.

16 FBIS Document ID: EUP20030313000029; Josef Joffe, "When the Worst Starts Coming to the Worst-Europe, Russia, and the United States: A Heap of Rubble Before the First Shot is Fired," Die Zeit, 13 March 2003. 
Table 2. Percentages of respondents to the question: Are you in favor of military action against Iraq ${ }^{17}$

\begin{tabular}{|c|c|c|c|c|}
\hline & $\begin{array}{c}\text { Under no } \\
\text { circumstances }\end{array}$ & $\begin{array}{c}\text { Only if } \\
\text { sanctioned by } \\
\text { the UN }\end{array}$ & $\begin{array}{l}\text { Unilaterally by } \\
\text { the U.S. and its } \\
\text { allies }\end{array}$ & $\begin{array}{l}\text { Don't know/ } \\
\text { no opinion }\end{array}$ \\
\hline Denmark & 45 & 38 & 10 & 7 \\
\hline Finland & 44 & 37 & 6 & 12 \\
\hline France & 60 & 27 & 7 & 6 \\
\hline Germany & 50 & 39 & 9 & 2 \\
\hline Ireland & 39 & 50 & 8 & 3 \\
\hline Luxembourg & 59 & 34 & 5 & 2 \\
\hline Netherlands & 38 & 51 & 7 & 5 \\
\hline Portugal & 53 & 29 & 10 & 8 \\
\hline Spain & 74 & 13 & 4 & 9 \\
\hline U.K. & 41 & 39 & 10 & 10 \\
\hline Iceland & 49 & 36 & 7 & 8 \\
\hline Switzerland & 45 & 45 & 5 & 5 \\
\hline Albania & 53 & 36 & 7 & 3 \\
\hline $\begin{array}{l}\text { Bosnia and } \\
\text { Herzegovina }\end{array}$ & 75 & 16 & 9 & 0 \\
\hline Bulgaria & 58 & 29 & 5 & 8 \\
\hline Estonia & 64 & 20 & 9 & 7 \\
\hline Macedonia & 76 & 13 & 4 & 8 \\
\hline Romania & 42 & 38 & 11 & 9 \\
\hline Russia & 59 & 23 & 7 & 11 \\
\hline
\end{tabular}

would continue to require the support of the full Bundestag. "Germany is not going to be able to wage war without the approval of parliament," he emphasized. ${ }^{18}$ The Bundestag granted Struck only a very small concession: exploratory and other small-

17 Iraq Poll 2003, available at: www.gallup-international.com/, accessed 19 February 2004.

18 Tom Levine and Bettina Vestring, "No Fast-Track Process for Missions: Struck Rebuffed by SPD - Green Bundestag Members," Berliner Zeitung, 27 November 2003. 
scale operations could take place, unless a Bundestag party group expressed reservations within a week. If so, then it too would require approval from the full Bundestag.

The other problem highlighted by the exercise was what some NATO officials call "usability." Very few of the forces that NATO allies have can be deployed quickly. Lord Robertson said, "Out of 1.4 million non-U.S. soldiers under arms, the eighteen non-American allies have about 55,000 deployed on multinational operations in the Balkans, Afghanistan and elsewhere, and yet they feel overstretched.... That is a situation that is unacceptable." ${ }^{, 19}$ Finally, it was made clear at the exercise that SACEUR was limited in his ability to plan for hypothetical contingencies. ${ }^{20}$

\section{How Sustainable?}

A problem that has not caught the attention of many European policy-makers is the question of the sustainability of the NRF, even with only a thirty-day requirement (which is half that of the Marine Expeditionary Brigade). Several U.S. military officers that I interviewed question the commitment of the Europeans to providing the materiel necessary to sustain operations abroad. ${ }^{21}$ They point out that no Western European country has sustained contested ground operations abroad above a battalion level without U.S. help since the Suez crisis in 1956. The mission the British were given in Iraq was designed to minimize the stress on their logistics train. Nevertheless, the chief of the British General Staff, General Sir Michael Walker, said in March 2004 that the U.K. would be able to mount an operation on the level of the Iraq conflict before the end of the decade: "We are unlikely to be able to get to large-scale (readiness) much before the end of the decade, somewhere around " 08 or ' $09 . " 22$ Without continuous exercises and experience from actual operations, and with continuing budgetary pressures that favor force structure over sustainability, European militaries may lack the ability to meet even the thirty-day requirement specified for the NRF.

\section{Continued Reliance on the United States}

When the NRF concept was first vetted, the United States said that it would not participate. This led several European generals to complain that the U.S. was not taking the proposal seriously. However, these generals were missing the point, since the objective was not to figure out how to improve interoperability between U.S. and European forces, but to spur the transformation of European forces. Whatever the initial U.S. reluctance, it quickly became clear that the Europeans lacked a number of important capabilities that would need to be provided by U.S. forces. These included strate-

19 Peter Spiegel, "War Game at NATO Talks Highlights the Need for Quick Deployment," Financial Times, 10 October 2003.

20 See http://www.analisidifesa.it/articolo.shtm/id/3523/ver/EN, accessed 9 January 2004.

21 Interviews, NATO School in Oberammergau, January 2004.

22 Richard Norton-Taylor, "Defence Chief Warns Forces are Overstretched," The Guardian (London), 25 March 2004. 
gic lift, bare-base deployable air forces, logistics sustainability, and theater-level ground surveillance.

Strategic lift has always been a sore point between the U.S. military and European militaries. The Europeans have sought to remedy this deficiency by buying a strategic air lifter from Airbus called the A400M. However, uncertainties regarding the size of the buy have delayed the initial operating capability of the system. France is now slated to take delivery of the first system in November 2009, and only thirty aircraft will be produced a year. ${ }^{23}$ The Europeans could compensate for their lack of strategic airlift by turning to strategic sealift, but the timelines for procurement in this arena are little better. ${ }^{24}$ NATO has assessed that it needs twelve to fourteen additional medium-size rollon/roll-off (Ro-Ro) vessels.

No European country has a battle management capability comparable to that of the E-8 Joint Surveillance Target Attack Radar System (Joint STARS), an airborne radar capable of tracking moving targets. Therefore, in the early rotations of the NRF, the U.S. is offering Joint STARS support. In the mid- to far term, NATO intends to buy an Air Ground Surveillance (AGS) capability based on the same model as the NATO AWACS. The AGS system would "provide synthetic-aperture radar imagery and ground moving-target-indication information in near-real time in order to support intelligence-gathering, time-sensitive targeting, and bomb-damage assessment." 25 However, even under the best of circumstances, this system would not be operational before 2010 .

Only the French have a bare-base deployable air headquarters; no other European country has such a capability. Since the NRF operates in eighteen-month rotation cycles (six months training, six months stand-by, and six months refitting), one deployable air headquarters is not enough. Aircraft carriers might work just as well during the other two cycles, but in truth the United States will clearly be called upon to fill in here as well.

\section{Double-Counting and the Comparison between the EU and NATO Intervention Forces}

At first blush, it would seem that the proposed EU Rapid Reaction Force would compete for the same forces as the NATO Response Force. Both forces seem to require intervention capabilities. But in theory this is not the case, as the missions of the two forces are different. The NRF is intended as a joint, short-notice, forced-entry expeditionary force of about 20,000 troops in which the land component is about a brigade. In contrast, the EU Rapid Reaction Force is intended for the full range of Petersberg missions, and is projected to be able to provide 60,000 troops within sixty days. Its

23 "Last Call for New A400M Industrial Participants," International Defense Review, 1 April 2004.

24 "NATO Nations Sign up for Sealift," Jane's Navy International, 1 March 2004.

25 "NATO's Airborne Surveillance Competition Enters the Final Stretch," International Defense Review, 1 January 2004. 
mission is closer to that of a stabilization force than it is to a long-notice expeditionary force. The NRF is an on-call force, while the exact troops involved in an EU-led expedition would be determined by a troop conference.

Nevertheless, certain European politicians view the NRF as simply a more responsive EU Rapid Reaction Force. The German Defense Minister Peter Struck said in November 2002, "[T] he missions of the NATO force will differ from the EU crisis reaction force only to the extent that it is to be available more rapidly." ${ }^{26}$ Some European politicians see little difference between the two. This view was expressed by Struck's counterpart at the Foreign Ministry, Joschka Fischer. ${ }^{27}$ And Struck's French counterpart, Michele Alliot-Marie, expressed a similar idea: "The two intervention forces must supplement each other, they must not be rivals. The NATO Response Force must also not have priority over the European Rapid Reaction Force. Situations can occur, in which the EU would like to intervene without NATO considering it appropriate, and the other way around. For instance, the EU will probably replace NATO soon in Macedonia and in Bosnia." 28

However, theory often flies in the face of practical exigencies-like constrained budgets. Some of the smaller countries will be stretched to offer a contribution to either force, and they lack the resources to contribute to both. ${ }^{29}$ Moreover, even the richer countries will find their defense budgets under increasing pressure in the face of mounting social costs. The recent German defense reform called for a division of forces into those capable of intervention, stabilization, and homeland defense. The Germans intend to fund 17,000 forces capable for intervention - only enough to meet the requirements of both the EU rapid response force and the NATO Response Force. However, successive German governments have revised their defense budgets downward, and the expensive intervention forces may prove a lucrative target in the future. In fact, as German forces have taken on more and more missions, their budget has been reduced, prompting one respected German newspaper to say, "The Bundeswehr is in a miserable state." 30

\section{Conclusions}

However effective a vehicle the NRF may be for transformation, it is unlikely to be used for sustained force-entry brigade-sized expeditionary operations. Fortunately, the requirement for such operations remains low. The NRF may be used for show operations, such as the European Rapid Reaction Force conducted in Rwanda in June 2003, but it is unlikely to be deployed in any situation where there is a clear risk of combat.

26 Buechner, "Not Every Country.",

27 Rainer Koch, Florian Güssgen, Christian Thiele, and Hubert Wetz, "Fischer Opposes Division of Labor Between EU and NATO," Financial Times Deutschland, 20 November 2002.

28 Romain Leick, "'There Is no Automatic War'; French Defense Minister Alliot-Marie on the Iraq Crisis, Establishment of a European Defense Union and the Relationship with NATO," Der Spiegel, 2 December 2002.

29 Interviews, Sofia, January 2004.

30 "Building Castles in the Air," Frankfurter Allgemeine Zeitung, 12 March 2004. 
However prepared the forces themselves may be, political factors may prevent them from being used rapidly, if at all. The October 2003 NATO exercise (called a "study seminar" because of political sensitivities, rather than a "war game" or "exercise") made clear that political procedures for authorizing the use of force could severely hamper the deployment and use of forces. An attempt to streamline that process in Germany ran into political obstacles. Thus, the speed with which NATO could respond to a crisis depends on political factors. Even for those countries that do not need parliamentary approval for short-term deployments, such as France, there remain questions as to whether UN authorization is required. If recent history is any guide, unanimity within the UN Security Council may be slow in coming, if it comes at all. It is certain most countries are uncomfortable with the notion of pre-emptive strikes.

The NRF will continue to rely on U.S. capabilities to top up the force at least until 2010, and perhaps much longer than that. This reliance on the U.S., along with budgetary pressures, may delay European procurement decisions even longer, and adversely affect the process of European defense transformation.

Still, at the end of the day, the NRF will provide the best vehicle for transforming the European militaries. Unlike the EU Rapid Reaction Force, where the emphasis is on improving the capabilities rather than the performance of the force, the NRF will serve as a vehicle for improving performance. The needs of the mission will drive the transformation of the European forces' capabilities, logistics and support systems, and the political means of authorizing action. Because the NRF is a multinational force, shortfalls will appear among the various countries participating. However, without the NRF serving as a standard, the participating countries would be much more likely to fall behind in transforming their forces when left to their own devices. 


\section{Bibliography}

Binnendijk, Hans, and Richard Kugler. "Transforming European Forces." Survival 44, no. 3 (2002): 117-132.

Buechner, Gerold. "Not Every Country Must Be Able to Do Everything'-Defense Minister Struck on NATO Response Force, the Defense Budget, and Iraq." Berliner Zeitung (2002).

Cordesman, Anthony H.. The Lessons of Afghanistan. Washington, D.C.: Center for Strategic and International Studies, 2002.

Cornish, Michael Clarke and. "The European Defence Project and the Prague Summit." International Affairs 78, no. 4 (2002): 777-788.

Erlanger, Steven. "Rumsfeld Urges NATO to Set Up Strike Force." New York Times (2002).

Germany Sets Terms for Backing NATO Rapid Reaction Force. Deutsche PresseAgentur (2002).

Hemingway, Al. "At the Tip of the Anti-terrorism Spear: Though little known, the U.S. Marines maintain special anti-terrorism units." VFW Magazine (2002).

Koch, Rainer, Florian Güssgen, Christian Thiele, and Hubert Wetz. "Fischer Opposes Division of Labor Between EU and NATO." Financial Times Deutschland (2002).

Leick, Romain. "'There Is no Automatic War'; French Defense Minister Alliot-Marie on the Iraq Crisis, Establishment of a European Defense Union and the Relationship with NATO." Der Spiegel (2002).

Levine, Tom, and Bettina Vestring. "No Fast-Track Process for Missions: Struck Rebuffed by SPD - Green Bundestag Members." Berliner Zeitung (2003).

Norton-Taylor, Richard. "Defence Chief Warns Forces are Overstretched." The Guardian (2004).

Spiegel, Peter. "War Game at NATO Talks Highlights the Need for Quick Deployment." Financial Times (2003).

Vick, Alan, David Orletsky, Bruce Pirnie, and Seth Jones. The Stryker Brigade Combat Team: Rethinking Strategic Responsiveness and Assessing Deployment Options. Santa Monica, CA: The RAND Corporation, 2002. 